REVIEW PAPER

\title{
Indigenous Fermented Foods of India with Special Reference to Andhra Pradesh and Adjoining Areas
}

\author{
Lebaka Veeranjaneya Reddy ${ }^{1 *}$ and V.K. Joshi ${ }^{2}$ \\ ${ }^{1}$ Department of Microbiology, Yogi Vemana University, Kadapa, Andhra Pradesh, India \\ ${ }^{2}$ Former Department of Food Science and Technology and Management, Y.S. Parmar University of Horticulture and \\ Forestry, Solan, India
}

*Corresponding author: lvereddy@yahoo.com

Paper No.: 232

Received: 28-06-2019

Revised: 24-10-2019

Accepted: 27-11-2019

\begin{abstract}
Indigenous or traditional fermented foods have been prepared and consumed world over including South Asia for hundreds of years and are strongly linked to cultures and traditions of millions of people around the world, especially in rural communities. A food is considered fermented when one or more of its constituents have been acted upon by selected microorganisms or their enzymes to produce a significantly altered final product desirable for human consumption. Most fermentations are caused by molds, yeasts, or bacteria, either singularly or in combination. The origins of most fermentation technologies have been lost in the mists of history. Some products and practices no doubt fell by the wayside; those that remain today have survived the test of time. Indigenous Fermented food products are important components of the diet as staples, adjuncts to staples, condiments, and beverages. There a need to protect our traditional technology and foods that are very valuable. In this review we have given a brief account on traditional/indigenous fermented foods (preparation methods, microbes involved, biochemical changes and preservation techniques) especially of Andhra Pradesh (AP), India.
\end{abstract}

Keywords: Fermented foods, olds, yeasts, bacteria, traditional technology

Traditional foods are generally categorized into fermented foods and non-fermented food. Fermented foods are prepared by the action of microorganism(s), either naturally or adding starter culture (s), which modify the substrates biochemically and organoleptically into edible product, and are thus, generally palatable, safe and nutritious (Pederson, 1960; Tamang and Holzapfel, 1999; Hansen, 2002; Campbell-Platt, 1987; Achaya, 1998; Joshi, 2016; Molinos et al. 2016). These inexpensive culturally acceptable traditional foods provide basic diet as staple, pickle, confectionery, condiment and alcoholic beverages, which supplement enhanced nutrition, palatability, wholesomeness of the product with acceptable flavor and texture (Steinkraus, 1967;
Joshi, 2012). Most of them are common while other fermented foods are less familiar and confined to particular community and places. For food fermentations by molds, yeasts, or bacteria, either singularly or in combination are used. Indigenous or traditional fermented foods have been prepared and consumed by the people around the world, especially in rural communities. The origins of most fermentation technologies have been lost in the mists of history. Some products and practices no doubt fell by the wayside; those that remain today have survived the test of time. Fermented food products

How to cite this article: Reddy, L.V. and Joshi, V.K. (2019). Indigenous Fermented Foods of India with Special Reference to Andhra Pradesh and Adjoining Areas. Int. J. Food Ferment. Technol., 9(2): 73-87.

Source of Support: None; Conflict of Interest: None 
are important components of the diet as staples, adjuncts to staples, condiments, and beverages.

\section{FERMENTED FOODS}

A food is considered fermented when one or more of its constituents have been acted upon by selected microorganisms or their enzymes to produce a significantly altered final product desirable for human consumption. This oldest form of food biotechnology originated as a necessity for enhancing the keeping quality of diverse plant and animal food materials through organic acid, alcoholic, and alkaline fermentations. Fermentation, a relatively efficient low-energy preservation process, also improves digestibility, flavor, appearance, nutrientcontents, and other quality attributes and reduces antinutritional components of the substrates and cooking time (Nouts, 2001). Many fermented foods are now receiving global attention for their health-promoting or disease- preventing or -curing effects. Whereas a considerable number of food fermentation processes have been scaled up for commercial purposes, most types of fermented foods are still produced on a home scale. Such products often contain mixed genera and populations of microorganisms because of the lack of controlled processing facilities. In view of larger-scale industrialized food fermentation, microbial ecology and metabolic activities of functional microorganisms must be investigated. Present-day developments in molecular methods enable accurate characterization of strains and development of tailor-made fermented food products (Adams 1999).

Three major types of microorganisms are associated with traditional fermented foods and beverages (Ray and Joshi (2014) and these are:

\section{Microorganisms associated with fermented foods}

- Filamentous fungi: Species of Aspergillus, Amylomyces, Aciinomucor, Monascus, Mucor, Neurospora, Penicillium and Rhizopus.

- Yeasts: Species of Candida, Debaryomyces, Geoirichum, Hansenula, Kluyveromyces, Pichia, Saccharomyces, Saccharomycopsis, Torulopsis and Zygosaccharomyces.

- Bacteria: Species of lactic acid bacteria
(LAB)- Lactobacillus, Lactococcus, Leuconostoc, Enterococcus, Pediococcus, Tetragenococcus and Streptococcus, Species of Acetobacter, Citrobacier, Klebsiella, Bacillus, Brevibacterium and Propionibacterium.

\section{Types of Fermented foods}

A variety of fermented foods can be found widespread over the world and the foods are prepared in India are presented in Table 1, some of them, made in Andhra Pradesh are described in this review. Indigenous fermented foods can be divided into the following types depending up on the substrate used:

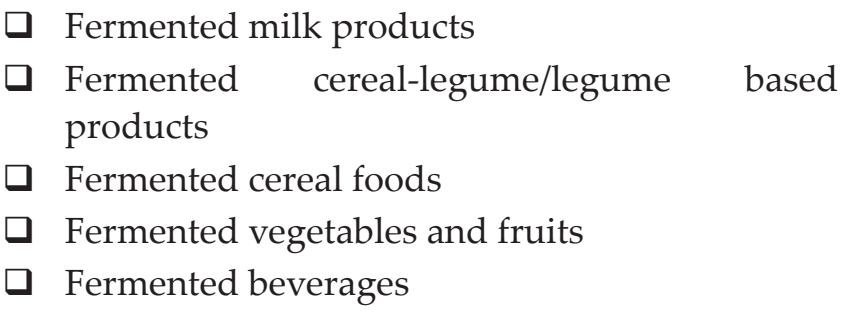

\section{FERMENTED MILK PRODUCTS}

Fermented milk products have nutritive and medicinal value. Being tropical region in the south India, the sour milk preparation started ages ago because of that it is more stable and contain high quality nutrients compared to the fresh milk (Mann 1977).

\section{Dahi/Curd}

This is one of the most popular and oldest Indian fermented milk products, known for its milk acidic taste and pleasant flavour and is equivalent to western yogurt (Laxminarayana and Shankar, 1980). The Aryans made a virtue of it so much so that it is must in the Indian daily menu. Curd is said to create relish for food, promote appetite, operate as emollient and increase strength. A good quality dahi is firm and of uniform consistency with sweet flavor and acidic taste. The surface is smooth and glossy and usually a cut surface is trim ad free from cracks and gas bubbles.

Preparation of curd/dahi is probably originated for the preservation of surplus milk. The inocula 
Indigenous Fermented Foods of India with Special Reference to Andhra Pradesh and Adjoining Areas

P

Table 1: Common traditional fermented foods/beverages of India

\begin{tabular}{|c|c|c|c|}
\hline Food & Substrate & Microorganism & Nature and use \\
\hline \multicolumn{4}{|c|}{ Traditional Fermented Products of South India } \\
\hline$\overline{l d l i}$ & Rice-black gram & $\mathrm{LAB}$, yeasts & $\begin{array}{l}\text { Steamed, spongy cake; breakfast } \\
\text { food }\end{array}$ \\
\hline \multirow[t]{2}{*}{ Dosa } & Rice-black gram & LAB, yeasts & Spongy pan cake, shallow fried \\
\hline & & B. amyloliquefaciens & staple food \\
\hline Dahi & Milk & $\mathrm{LAB}$ & \\
\hline Butter milk & & LAB, Bacillus ssp. & $\begin{array}{l}\text { Sweet/sour beverage use to take } \\
\text { along with rice }\end{array}$ \\
\hline Lassi & & LAB, Bacillus ssp & Sweet and flavoured beverage \\
\hline Ambali & Millet, rice & LAB, yeast and Bacillus ssp & Steamed sour cake, staple food \\
\hline Kanji & Carrot or beet roots & $\begin{array}{l}\text { Starter culture used is } \\
\text { TORANI } \\
\text { Which contains LAB, Yeasts }\end{array}$ & $\begin{array}{l}\text { Strong flavored alcoholic } \\
\text { beverage's }\end{array}$ \\
\hline \multicolumn{4}{|c|}{ 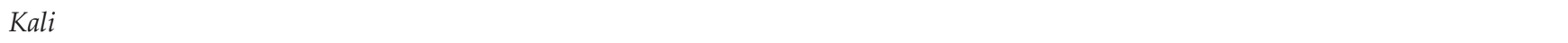 } \\
\hline Papadam & Black gram & LAB & \\
\hline Pickles & $\begin{array}{l}\text { Matured fruits and } \\
\text { vegetables }\end{array}$ & & \\
\hline Toddy/Palm wine & $\begin{array}{l}\text { Sap from inflorescence/ } \\
\text { trunk of palm plants }\end{array}$ & & \\
\hline Sara & $\begin{array}{l}\text { Black jiggery and plant } \\
\text { bark }\end{array}$ & Yeast, LAB and Acetobacter & \\
\hline \multicolumn{4}{|c|}{ Traditional fermented products of North India } \\
\hline Ballac & Black gram & LAB, Yeasts, B. subtilis & Deep fried patties, snack \\
\hline Vadai & Black gram & LAB, Yeasts, B. subtilis & Deep fried patties, snacks \\
\hline Papad & Black gram & LAB, Yeasts. & Circular wafers, snacks \\
\hline wari & Black gram & LAB, Yeasts. & $\begin{array}{l}\text { Ball like hollow, brittle, } \\
\text { condiment }\end{array}$ \\
\hline Bhatura & Wheat & LAB & $\begin{array}{l}\text { Flat deep fried, leavened bread, } \\
\text { snack }\end{array}$ \\
\hline Nan & Wheat & Yeasts, LAB & $\begin{array}{l}\text { Leavened flat baked bread, staple } \\
\text { food }\end{array}$ \\
\hline Jalebi & Wheat & LAB, Yeasts & $\begin{array}{l}\text { Crispy, deep fried, pretzel sweet } \\
\text { confectionery. }\end{array}$ \\
\hline Paneer & Milk & $\mathrm{LAB}$ & $\begin{array}{l}\text { Soft mild flavored cheese, fried, } \\
\text { curry }\end{array}$ \\
\hline \multicolumn{4}{|c|}{ Traditional fermented products of western regions of a India } \\
\hline Dkokla & Bengal gram & LAB, yeasts & Steamed, spongy cake; snack \\
\hline Khamam & Bengal gram & $\mathrm{LAB}$ & Spongy cake; breakfast food \\
\hline Rabadi & $\begin{array}{l}\text { Wheat/pear-millet/ maize/ } \\
\text { barley buttermilk mixture }\end{array}$ & LAB, Bacillus spp. & Cooked paste; staple food \\
\hline Sl,rikJrand & Milk & $\mathrm{LAB}$ & Concentrated sweetened, savory \\
\hline \multicolumn{4}{|c|}{ Traditional Fermented Products of Eastern Regions of India } \\
\hline MistidalJi & Milk & LAB & Thick gel, sweet savory \\
\hline Tari & Datepalm & Yeasts, LAB & $\begin{array}{l}\text { Sweet cloudy white alcoholic } \\
\text { beverage }\end{array}$ \\
\hline
\end{tabular}


Reddy and Joshi

\begin{tabular}{|c|c|c|c|}
\hline \multicolumn{4}{|c|}{ Traditional Fermented Products of the Himalaya } \\
\hline Kinema & Soybeans & $\begin{array}{l}\text { Bacillus subtilis, Enterococcus } \\
\text { faecium, yeasts }\end{array}$ & $\begin{array}{l}\text { Sticky with typical flavor; side- } \\
\text { dish curry }\end{array}$ \\
\hline Hawaijar & Soybeans & Bacillus spp. & -do- Fish substitute \\
\hline Gundruk & Leafy vegetables & $\mathrm{LAB}$ & $\begin{array}{l}\text { Sun-dried, sour-acidic taste; soup/ } \\
\text { pickle }\end{array}$ \\
\hline Sinki & Radish tap root & LAB & - do- \\
\hline Mesu & Bamboo shoot & LAB & Sour-acidic pickle \\
\hline Laanr & $\begin{array}{l}\text { Finger-millet/rice maize/ } \\
\text { barley }\end{array}$ & $\begin{array}{l}\text { Starter culture used is Mrrcha } \\
\text { which contains Filamentous } \\
\text { moulds, Yeasts, LAB }\end{array}$ & $\begin{array}{l}\text { Mild alcoholic, slightly sweet- } \\
\text { acidic beverage }\end{array}$ \\
\hline
\end{tabular}

Source: Soni and Sandhu 1986.

used in preparation are mixture of lactobacillus and streptococci spp. Generally, a small quantity of the curd from previous fermentation is used as inoculum. Acceptable quality dahi could be obtained with the application of acid producing as well as flavor (primarily diacetyl)-producing micro-organisms and adopting two-stage fermentation. Biotechnological innovations suggest inclusion of certain probiotic and beneficial bacteria for further enhancement in the dietetic properties of traditional dahi. Application of bio-preservatives and thermization (mild heattreatment) may be recommended for shelf-life extension of dahi to extend the market reach (Gandhi, 1989). The commonly associated lactic microflora in the inoculum are lactobacillus lactis, Lactobacillus delbrucki, L. acidophilus, L. helveticus and S. thermophilus. Extensive research is carried out in NDRI (Karnal and Bangalore) covering important aspects such as determining lactic microflora in homemade and commercial samples; isolation of lactic culture from dahi and suitability of lactic culture in getting stable product of acceptable quality attributes; good quality; biochemical and microbiological changes occurring during fermentation (Sreenivasan and Benarjee, 1946; Laxminarayana et al. 1952; Attaie et al. 1987; Gandhi, 2002). Composition and quality of dahi vary widely from one locality to another as it is being prepared under different market and domestic conditions as well as types of milk, with variable chemical and bacteriological quality used for the preparation. However, the chemical composition of dahi has been reported as fat ranging from $5-9 \%$, protein $3.3-3.4 \%$, lactic acid $0.5-1.1 \%$, calcium $0.12-0.14 \%$ and ash 0.75 $-0.79 \%$

\section{Butter}

Butter is one of the important fermented dairy products, although little is consumed directly (Rangappa and Achaya, 1974). It is used in small quantities as table butter and the rest of the major portion is used in the preparation of ghee and clarified butterfat. From the fresh milk first curd is prepared and then, the curd is churned with wooden or metal churns, during which butter rises to the top and is removed. Unlike the trained west farmer, the Indian farmer knowledge is purely traditional and handed down from the ancient times like Vedas. After the cooperative movement in Gujarat, now the butter is preparing in many dairy farms in large quantities commercially. Most predominant microorganisms that are present in butter are lactobacilli followed by Streptococci, Coli-forms and aerobic spore formers. Yeasts and moulds also present in considerable number and contribute to acidity, colours and offflavor. S.lactis subssp diacetylactis produces the flavor compounds diacetyl, acetaldehyde, acetoin and carbon dioxide (Gandhi 1989). Butter has moisture conrent of $18-20 \%$, fat $78-81 \%$, non-fatty solids 0.7 $1.5 \%$, acidity $0.5-0.8 \%$ (as lactic acid), energy $680-760$ Kcal, Ca 400mg, Mg 30mg, Fe 0-15 mg, riboflavin 0.5 $\mathrm{mg}$, thiamine $0.1 \mathrm{mg}$ and niacin $2.5 \mathrm{mg}$.

\section{Ghee}

It is the Indian name for clarified butter fat and is mainly prepared from cow, buffalo, sheep or goat's milk. There is no cold storage for this and it has good shelf-life. It is prepared by heating the butter 
or churned curd at $100-140^{\circ} \mathrm{C}$ for $5-10 \mathrm{~min}$, which removes the water through evaporation. Then, is clarified using muslin cloth and cooled to solidify.

Ghee prepared from buffalo's milk has white colour but due to the presence of carotinoids ghee prepared from cow's milk is yellow in colour. All the microorganisms present in curd and butter are killed during heating process. So the ghee is free of microorganisms (Campbell-Platt 1987; Aneja 2002). Ghee contains water $0.1-1 \%$, protein $0.5-1 \mathrm{~g}$, ash $1-2 \mathrm{~g}$, energy $880 \mathrm{Kcal}$, Na 100 mg, K 20 mg, Ca 20 mg, Mg $2 \mathrm{mg}$, P 30 mg, S 10 mg, Niacin 0.2 mg, retinol 900 ug, carotene 550 ug and vitamin E 1.8 ug (Campbell-Platt 1987; Aneja 2002).

\section{Lassi}

It is also a popular fermented beverage made in India. Lassi is appreciated throughout the country as a beverage for its palatability and as thirst quenching/ refreshing drink. It is also known for its therapeutic values. The palatability and wholesomeness of the product depend on the quality of curd churned and temperature of churning. An average curd obtained by fermentation with contaminants produces a highly sour or off-flavored lassi, unfit for human consumption (Gandhi, 2002). In general, the preparation of lassi there are few steps such as:

A A add a little quantity of water to well set-curd in a container,

$\checkmark$ Addition of water will depend on the composition of curd.

- Homogenize the contents using curd beater,

口 Dilute the contents with 1-2 parts of cold water

- Add sugar at the rate of 14 to 20 per cent or add 1-2 per cent powdered common salt and mix the content.

The commonly associated lactic microflora in lassi include Lactobacillus lactis, Lactobacillus delbrucki, L. acidophilus, Lueconostoc mesenteroides, L.diacetyllactis, L. helveticus and S. thermophilus. To get good quality lassi, restricted fermentation with cultured microorganisms produces lassi with byproducts such as enhanced acetaldehyde and diacetyle (Gandhi, 1989). Composition of lassi vary widely with types of milk, with variable chemical and bacteriological quality used for the preparation.

\section{Butter milk}

It is a well known and highly consuming nonalcoholic dairy beverage in Andhra Pradesh and adjoining areas. Butter milk is prepared as homemade and commercial product as a by - product of butter making. Sometimes it contains small butter flakes (Lindsay et al. 1965). Because of its taste, nutrients and medicinal properties is a must with south Indian meal. It is prepared through natural fermentation of sour cream butter or from sweet and non-fermented cream. Traditionally it is prepared from churned dahil curd by diluting with water (Sarkar et al. 1996). The commonly associated lactic microflora in buttermilk are Lactobacillus lactis, Lactobacillus delbrucki, L. acidophilus, Lueconostoc mesenteroides, L.diacetyllactis, L. helveticus and S. thermophilus. To get good quality buttermilk restricted fermentation with cultured microorganisms such as enhanced acetaldehyde and diacetyle producing organisms are using. Generally the chemical composition of butter milk depends on dahi that used in preparation and large extent on butter making technology and season. It contains 9\% dry matter, lactose $4 \%$, lactic acid $0.5-1 \%$, nitrogenous compounds $3.3-4 \%$, ash $0.7 \%$ and fat content ranges from $0.3-0.6 \%$ (Agarwala and Sharma, 1961).

\section{FERMENTED CEREAL AND LEGUME BASED PRODUCTS}

\section{Dosa/Dosai}

Dosa is one of the very popular traditional fermented foods of South India. First reference to dosa occurs in Tamil Sangam literature from around $6^{\text {th }}$ century $\mathrm{AD}$ and Chalukya king Somaesvara III describe the dosa in 1051. Eminent food scientist K.T. Achaya said that dosa have a history of two thousand years in Dravidian region (Achaya, 1998). 
It is prepared from naturally fermented rice (Oryza sativa) and black gram (Phaseolus mungo) batter spreading 1:1 batter on a hot greasy griddle. More rice flour is used in dosa batter than idli batter. Dosa is prepared by the following steps:

- Soaking 3 parts rice and 1 part of black gram in water for 4-6h in ambient temperature 27-30 degree centigrade's,

G Grinding to a fine paste and mixing both to get a free running batter,

- $1 \%$ of salt is added to the batter and allowed to ferment overnight (10-16h). The natural mocroflora of both rice and dhal act as starter and bring about the fermentation.

a About $50-80 \mathrm{ml}$ of batter is poured on to a hot, oiled pan and fried until crisp and brown colour on one side then turned to second side, cook well and rolled.

- This crispy and roasted dosa served with either coconut chutney or with lentil-vegetable curry (Soni et al. 1985).

Traditional dosa batter fermentation has revealed the occurrence and role of several bacteria alone or in combination with yeasts in bringing about various biochemical changes (Sandhu et al. 1986; Soni et al. 1986). Leuconostoc mesenteroides, Streptococcus faecalis and Lactobacillus fermentum are predominant among bacteria while Saccharomyces cerevisiae, Debarvomvces hansenii, Trichosporon, Candida glabrata, C. tropicalis, C. sake, C. kruzsei, Hansenula and Trichosporon beigelii are the common yeasts involved in fermentation. Microbes present in dosa batter and the microbes that contributed from two substrates are as shown in Table 2. Dosa fermentation is accompanied by an increase in total acids, total volume, total solids, soluble solids, non-protein nitrogen, free amino acids, amylases, proteinases, vitamins B1 and B2 (Soni et al. 1985; 1986; Sandhu et al. 1986). Total nitrogen and total proteins do not very significantly where as reducing sugars and soluble proteins after declining initially tend to increase afterwards with the progress in fermentation. Dosa contains $35-40 \%$ water (on dry matter basis), $15-20 \%$, fat $15-25 \%$, carbohydrates $40-$ $50 \%$ fiber $5-8 \%$, ash $4-6 \%$ and energy $400-450 \mathrm{Kcal}$, vitamin $\mathrm{B}$, niacin, thiamine concentrations increased during fermentation (Soni et al. 1985).

\section{Biochemical changes and Improvements}

With the advent of fermentation acidity is increased and carbon dioxide is produced. The production of acid and gas in dosa and $i d l i$ is dependent upon bacteria while the yeasts contribute enzymes and esters which impart desirable flavours (Radhakrishnamurty et al. 1961; Steinkraus et al. 1967).

Table 2: Prevalence of different bacteria and yeasts in fermented dosa batter

\begin{tabular}{|c|c|c|}
\hline Microorganism & No. & $\%$ \\
\hline \multicolumn{3}{|l|}{ Bacteria } \\
\hline Leuconostoc mesenteroides & 33 & 94 \\
\hline Streptococcus faecalis & 30 & 85 \\
\hline Lactobacillus fermentum & 25 & 71 \\
\hline Bacillus arnyloliquefaciens & 20 & 57 \\
\hline Lactobacillus delbrueckii & 13 & 37 \\
\hline Bacilluspolymyxa & 5 & 14 \\
\hline Pediococcus cerevisiae & 5 & 14 \\
\hline Bacillus subtilis & 5 & 14 \\
\hline Micrococcus varians & 3 & 8 \\
\hline Enterobacter sp. & 3 & 8 \\
\hline \multicolumn{3}{|l|}{ Yeasts } \\
\hline Saccharomyces cerevisiae & 18 & 51 \\
\hline Debaryomyces hansenii & 15 & 43 \\
\hline Trichosporon beigeUi & 9 & 26 \\
\hline Hansenula anomala & 6 & 17 \\
\hline Torulopsis candida & 5 & 14 \\
\hline Oosporidium margaritiferium & 4 & 11 \\
\hline Candida robusta & 3 & 9 \\
\hline Trichosporon pullulans & 2 & 6 \\
\hline Kluyveromyces marxianus & 2 & 6 \\
\hline Candida kefyr & 2 & 6 \\
\hline Candida krusei & 2 & 6 \\
\hline Rhodotorula mucilaginosa & 1 & 3 \\
\hline Rhodotorula glutinis & 1 & 3 \\
\hline
\end{tabular}

Source: Soni and Sandhu 1986.

The biochemical and physiological characterization of the predominant microorganisms that yeasts Saccharomyces, Debaryomyces, Trichosporon and Hansenula help in the degradation of starch into 
maltose and glucose by producing extracellular amylolytic enzymes which are utilized by developing microbial load. Bacteria along with some yeast are mainly responsible for the production of acid and gas from simple sugars like glucose and maltose and thus account for its fall in $\mathrm{pH}$ and rise in volume with the progress in fermentation. Some strains of Saccharomyces cerevisiae also produce acid and gas from starch itself and may thus play a major role in dosa fermentation. Due to the ability of some strains to grow at high temperature $\left(42^{\circ} \mathrm{C}\right)$, Saccharomyces and Trichosporon along with bacteria also play a role in fermentation during summers when the temperature of the atmosphere exceeds $40^{\circ} \mathrm{C}$.

Table 3: Volatile flavour compounds identified by GC-MS analysis in 2 day stored Idli batter cultures

\begin{tabular}{lll}
\hline No & Heterocyclic compounds & Retention time (Min) \\
\hline 1 & Piperazinetrione & 11.5 \\
2 & Benzitriazole & 25.5 \\
3 & Imidazole & 37.0 \\
4 & Cyclohexylamine & 42.3 \\
5 & Chlorothiazide & 46.0 \\
\hline
\end{tabular}

Source: Renu Agarwal et al. 2000.

Further, it was observed in case of experimental fermentations carried out in our laboratory by self inoculating with different groups of micro-organisms that Leuconostoc mesenteroides and other acid producing bacteria mainly caused the acidification and leavening of the dosa batter while the yeasts Saccharomyces cerevisiae and Debaryomyces hansenii improved the nutritional quality of the batter in terms of flavour, total proteins, amino acids, vitamins and enzymes (unpublished data). According to Mukherjee et al. (1965), Steinkraus et al. (1967), the acid and gas required for souring and the leavening action in the idli batter are produced exclusively by the activity of hetero fermentative lactic acid bacteria Leuconostoc mesenteroides although there is a sequential change in the bacterial flora. Venkatasubbaiah et al. (1985) recently indicated that the gas production during idli batter fermentation depends upon the activity of the yeast flora belonging to Hansenula anomala, Candida glabrata, C. tropicalis, C. sake, C. kruzsei, Torulopsis candida, T. holmii and Trichosporon pullulans.

The values of nutritional constituents and organoleptic characteristics of dosa reveal that the product is very nutritious. There are many ways to improve its physical and biochemical characteristics by replacing the black gram, rice and restricted fermentation using selected known microorganisms. Attempts have been made to prepare dosa-like products with the replacement of black gram with sorgam, maize and bajra (Ragavendra Rao et al. 1979; Soni and Sandhu 1990). Especially S. cerevisiae in combination with the natural bacterial flora can play a significant role in further improving the nutritional quality and acceptability of dosa (Soni et al. 1989a and b). Further, Soni et al. (1989b) studied the replacement of the legume component and fermentation and fermentation can be satisfactorily performed in dosa batter by choosing suitable proportions of the ingredients. Mung beans, for example, rich in soluble compounds, and soybeans rich in proteins and enzymes, and they stated that can be used in combination with black grams which impart attractive organoleptic characteristics for further improving the digestibility and nutritional value of traditional dosa.

\section{Idli}

Idli is a very popular traditional fermented breakfast food staple consumed in the Indian subcontinent, especially in southern parts (Joshi et al. 2011). The major ingredients are rice (Oryza sativum) and black gram (Phaseolus mungo). Idli (and the process of steaming) was known in Southern India by as early as $700 \mathrm{CE}$. The process of steaming was influenced from Indonesia subsequently between 800-1200 $\mathrm{CE}$, giving rise to the modern day Idli. Traditional Idli preparation is depicted in Fig. 1, and briefly as follows: 1. Soaking the polished parboiled rice and decorticated black gram separately for $4-5 h$ at $30 \pm 1 \mathrm{C}$ in water. 2. After draining the water, grind the rice and black gram separately to $0.5-$ to $0.7-\mathrm{mm}$ particle size batter with occasional addition of water during the grinding process. 3 . Mixing rice and black gram 


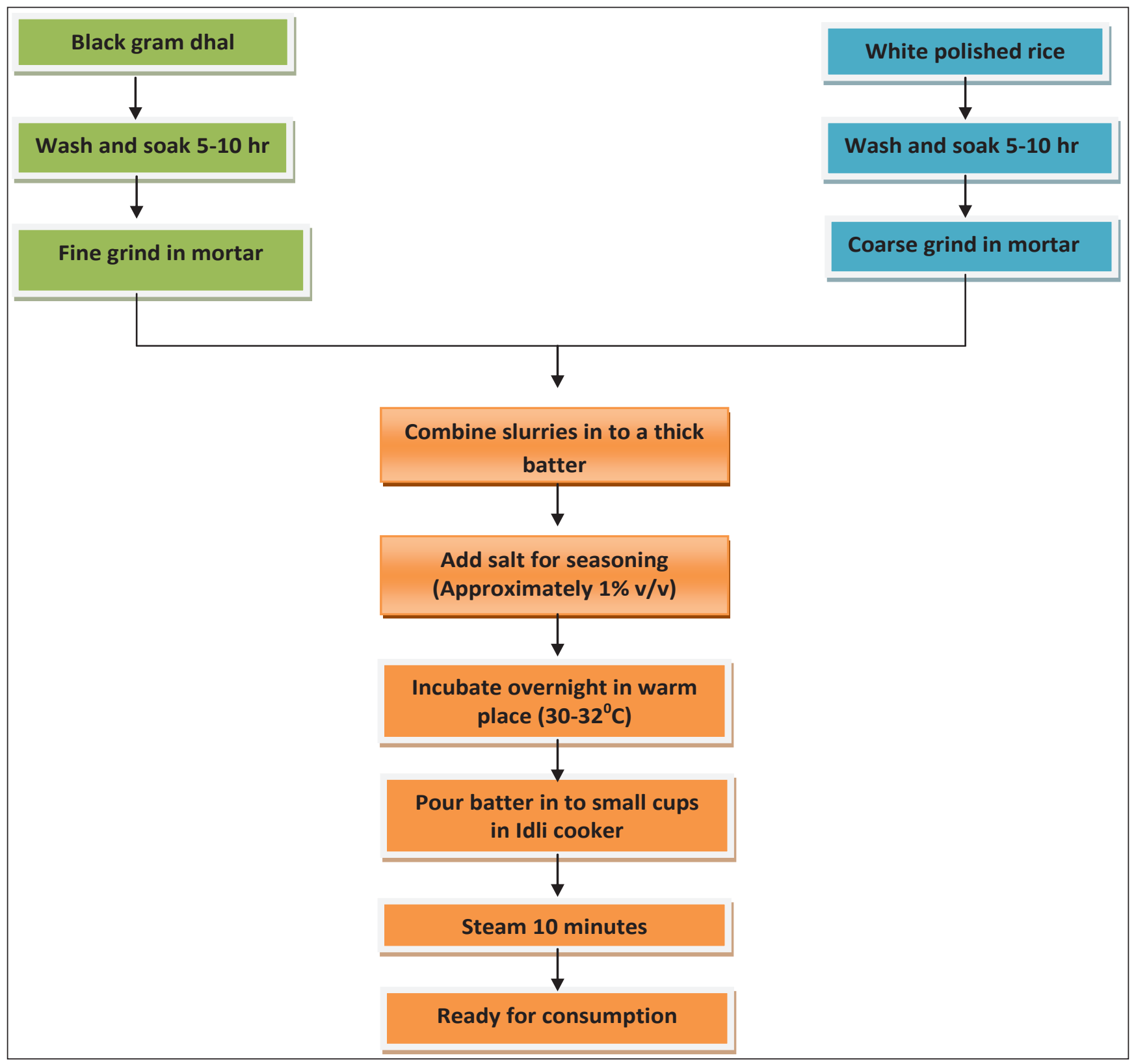

Fig. 1: Flow chart for Idli production

batters together in ratios of 2:1, 3:1 and 4:1 (v/v) batter were allowed for fermentation $(0,6,12,18$ and $24 \mathrm{~h})$ adding $2 \%$ of salt. 4 . Allowing to ferment overnight at room temperature. 5. Depositing the fermented batter in special Idli pans and steaming for $5 \pm 8$ min (Balasubramanium et al. 2006). It may have been found that the rice helped speed the fermentation process. Although the ingredients used in preparing idli have changed, the preparation process and the name have still remained the same.

The production of acid and gas in idli is dependent upon bacteria while the yeasts contribute enzymes and esters which impart desirable flavours (Radhakrishnamurty et al. 1961; Steinkraus et al. 1967). The lactic acid bacteria Leuconostoc mesenteroides, Streptococcus faecalis, Lactobacillus 
delbrueckii, Lactobacillus fermenti, Lactobacillus lactis and Pediococcus cerevisiae, Pediococcus pentosaceus have been found to be responsible for the fermentation process, although L. mesenteroides and S.faecalis are considered to be the microorganism essential for leavening of the batter and for acid production in idli (Purushothaman et al. 1993; Ramakrishnan 1993). Yeast fermentation occurs overnight by the joint action of Torulopsis candida (Saito) Trichosporon pullulans (Lindner). In large cities, baker's yeast is used. Idli batter fermentation has been the subject of many research investigations covering aspects of optimization of ingredients, microbiological, physico-chemical and nutritional (Steinkraus et al. 1967; Ramakrishnan 1979; Venkatasubbaiah et al. 1984; Thyagaraja et al. 1991 and 1992). Two significant changes occurring in idli batter fermentation are leavening and acidification. These two parameters have been used as the criteria for judging the progress of fermentation. The percent total acidity of $i d l i$ batter at different period of fermentation ranged between 0.44 to $0.91 \%$ (Ghosh and Chattopadhyay, 2010). Black gram, the leguminous component of idli batter serves not only as an effective substrate but also provides the maximum number of microorganisms for fermentation. These levels have been reported as ideal parameters reached in $12 \pm 14 \mathrm{~h}$ of fermentation for obtaining acceptable products (Soni \& Sandhu, 1990). In naturally fermented batter, within a period of 2 days, the $\mathrm{pH}$ and acidity levels were not organoleptically acceptable. The surface-active proteins and polysaccharides of black gram are well conditioned to retain a large volume of gases to give soft and fluffy texture.

Idli contains protein 14\%, carbohydrates 35-50\%, fat $0.2 \%$, Ca $80 \mathrm{mg}$, Fe $3.5 \mathrm{mg}$. The vitamins content of idli batter per $100 \mathrm{~g}$ are $0.59 \mathrm{mg}$ riboflavin, 0.59 $\mathrm{mg}$ thiamine and $0.76 \mathrm{mg}$ folic acid and energy $65 \mathrm{Kcal} / \mathrm{idli}$. It has also been reported that during fermentation, vitamins $\mathrm{B}$ and $\mathrm{C}$ increase, and also phytate is hydrolyzed almost to $50 \%$. L. mesenteroides (leavening) and S. faecalis (acid production) develop concomitantly at soaking stage and continue to multiply following grinding (Mukherjee et al. 1965).
These changes during fermentation are highly significant for nutritional point of view. An increase in methionine, a limiting essential amino acid in legumes, greatly improves protein value.

\section{Papadam}

These are flat, spicy, circular wafers from South India. Prepared from flour paste of dehulled black gram and fermented 4 to 6- hours. These are thin, dried, crispy, circular tortilla like wafers made up of legumes, cereals or starch crop flour eaten as snake or with meal by deep fried or roasted (Sankaran 1998). The dough is prepared and rolled into wafers of around $10-20 \mathrm{~cm}$ in diameter and $0.5 \mathrm{~mm}$ thickness. These are then fermented and dried in open air for 4-6 h. Soni and Sandhu, (1990) isolated bacteria and yeast from papdams. There are three different types of bacteria present and Leuconostoc mesentoroids is the most common along with Lactobacillus fermentum and $S$. faecalis. Fermentation increase the soluble solids and decrease in reducing sugars. The batter amount increases with duration of the fermentation. It contains the PH 5, total acids $0.7 \%$, total nitrogen is remain same, amylase is decrease and vitamin B1, B2 and B12 increased.

\section{FERMENTED CEREAL FOODS}

\section{Ambali}

Fermented product of South and East Indian cereal grass called ragi [Eleusine coracana (L.) Gaertn.] rice. In olden days it was taken as breakfast. People think this is very energetic and good for health. In villages of Andhra Pradesh people prefer this at working places where they need energy. Sometimes this takes with butter milk, green chilli, onions and pickles which give better taste (Ramakrishnan, 1979). Ragi flour is made into a thick batter with water and allowed to ferment for 14 hours. The fermented ragi batter is then added to cooked rice while stirring to avoid lump formation. It is allowed to cool, mixed with sour buttermilk, and consumed. The microorganisms are Leuconostoc mesenteroides (Tsenk.) V. Tieghem, Lactobaci fermentum Beij., Streptococcus faecalis and 
Saccharomyces sp. The $\mathrm{pH}$ usually decreases from 6.4 to 4.0 and volume increases by about $20 \%$, indicating $\mathrm{CO}_{2}$ production (Ramakrishnan, 1979).

\section{Kali}

It is one of the indigenous fermented rice products in AP, India. To leftover cooked rice, water is added, and the mixture is allowed to ferment overnight. This generally prepare in summer season because of the high temperatures in the nights. People in AP believes that Kali cools the body and very good for health (Sekar and Muniyappa, 2007). The microorganisms are Leuconostoc mesenteroides, Lactobaci fermentum Beij. Yeast such as Hansnula, Candida, Saccharomyces sp.

\section{FERMENTED FRUITS AND VEGETABLES}

\section{Pickles}

Pickling is one of the oldest methods of food preservation. Pickles are one of the important consumer products (Joshi et al. 2013). The important pickles in India are mango, drumstick, brinzal, gongura, mirchi pickle, chicken pickle, mutton pickle, fish pickle and prawn pickle. Pickles are one of the earliest commercial products appeared in the market (Verma and Joshi, 2000). In Orissa and Andhra Pradesh, the people are consuming the various pickles in daily diet. Pickles are consumed along with staple food such as rice, chapathi, bread, samosa, upma, etc. Particularly in both states particularly in tribal areas, raw material availability is high. Thus pickles making units can be promoted in tribal areas (Sekar and Muniyappa, 2007). Fully matured fresh vegetables, fruits, are washed and cut into required sizes and add salt, mirchi, oil and other ingredients in required quantity. The preparation of all picles is similar and very popular mango pickle in AP is depicted in Fig. 2. The freshly prepared pickles are to be cured for a week and packed in different sizes with labeling and dispatched for market in commercial preparations. The same process also for non-veg pickles. The durability of the non-veg pickles is very short. The addition of salt to the pickles restricts gram negative bacteria and enhance the growth of lactic acid bacteria. In all types of pickles the dominant organisms are Leuconostoc mesenteroids, L.pallax and Lactobacillus plantarum including these Staphylococcus aureus, Saccharomyces cerevisiae and A. niger also present when pickle spoiled.

\section{INDIGENOUS FERMENTED BEVERAGES}

Toddy and palm wine are alcoholic beverages that are made by fermenting the sugary sap from various palm plants. Virtually any sugary plant sap can be processed into an alcoholic beverage - it just needs the correct yeasts, temperature and processing conditions (Joshi, 2016). Throughout the world, alcoholic drinks are made from the juices of locally grown plants including coconut palm, oil palm, wild date palm, nipa palm, raphia palm, Caryota palm and kithul palm.

\section{Palm Wine}

Palm wine is the fermented sap of certain varieties of palm trees including raphia palm (Raphia hookeri or $R$. vinifera) and the Caryota palm (Jeeluga). It is collected by tapping the top of the trunk. There are many variations of the same product and no individual method or recipe. Palm wine is particularly common South India (Shamala and Sreekantiah, 1988. The sap use to collect from a growing palm. It is collected by tapping the palm. This involves making a small incision in the bark of the palm, about $15 \mathrm{~cm}$ from the top of the trunk. A clean gourd is tied around the tree to collect the sap, which runs into it. The sap is collected each day and should be consumed within 5-12 hours of collection. Fresh palm juice is a sweet, clear, colourless juice containing 10-12 percent sugar. The sap is not heated and the wine is an excellent substrate for microbial growth. It is therefore essential that proper hygienic collection procedures are followed to prevent contaminating bacteria from competing with the yeast and producing acid instead of alcohol (Fig. 3). Fermentation starts soon after the sap is collected and within an hour or two becomes reasonably high in alcohol (up to $4 \%$ ). If allowed to continue to ferment for more than a day, it starts turning into vinegar. The quality of the final wine is 


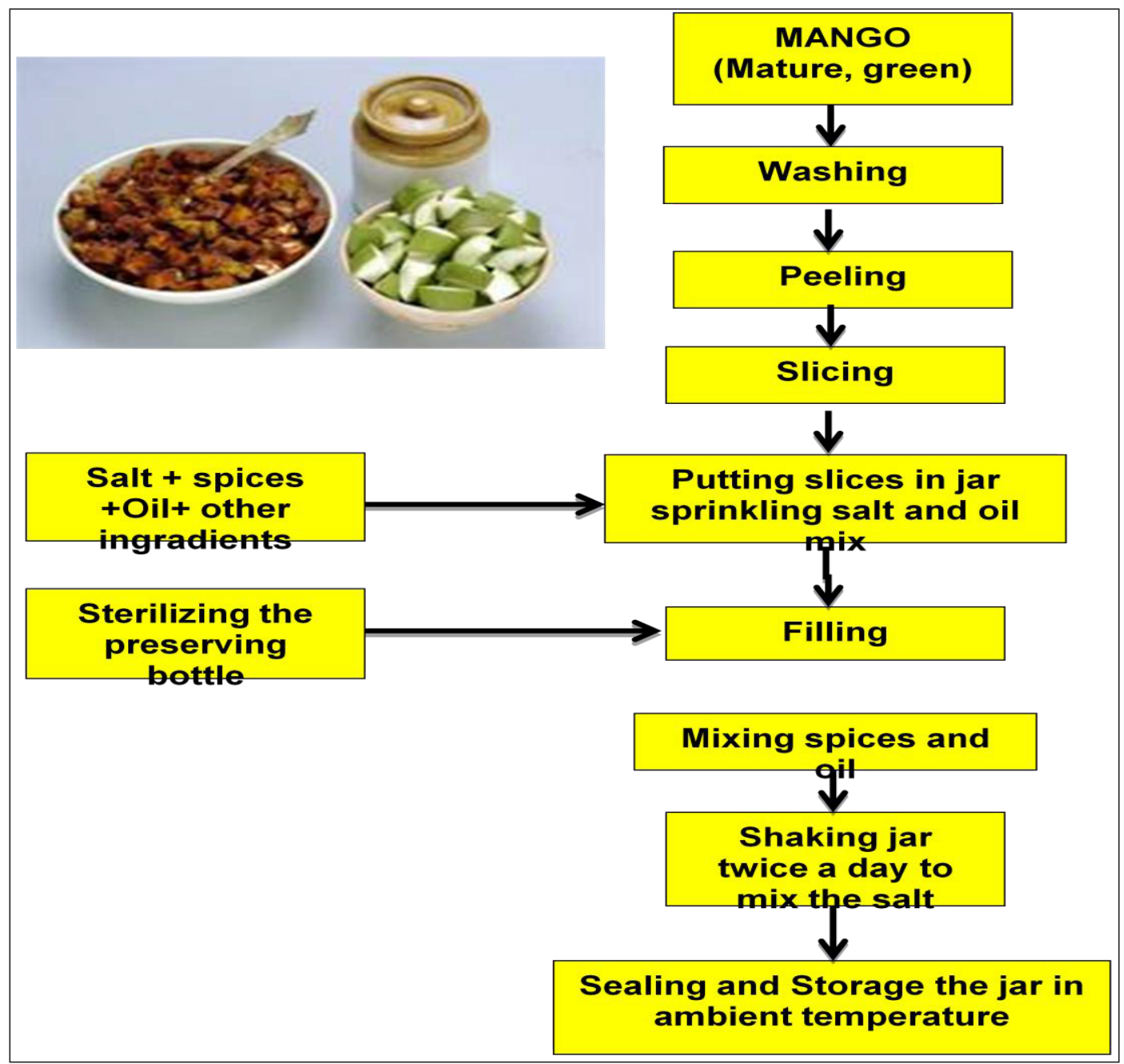

Fig. 2: Flow chart of mango pickle preparation

determined by the conditions used for the collection of the sap. Often the collecting gourd is not washed between collections and residual yeasts in the gourd quickly begin the fermentation. This is beneficial as it prevents the growth of bacteria which can spoil the sap (Grimwood and Ashman, 1975). Packaging is usually only required to keep the product clean and to transport it for its relatively short shelf life. Clean glass or plastic bottles should be used. The product should be kept in a cool place away from direct sunlight.

\section{Toddy}

Toddy is an alcoholic drink made by the fermentation of the flower sap from a coconut palm (Cocus neusifera). Fresh coconut sap contained $12-15 \%$ of sucrose (by weight) and trace amount of reducing sugar including glucose, fructose, maltose and raffinose. The sap contains approximately $0.23 \%$ protein, $0.02 \%$ fat. Half of the total sugars are fermented during first 24 hours and ethanol content of the fermented palm sap reaches maximum of $5.0-5.28 \%(\mathrm{v} / \mathrm{v})$ after $48 \mathrm{~h}$ (Sekar and Mariappan 2005 and 2007). After fermentation it is white and sweet with a characteristic flavour and contains between 4 and $6 \%$ alcohol. There are two main types of kallu in Andhra Pradesh, namely Thadi kallu (from Toddy Palmyra trees) and Eetha kallu (from silver date palms). Eetha Kallu is very sweet and less 


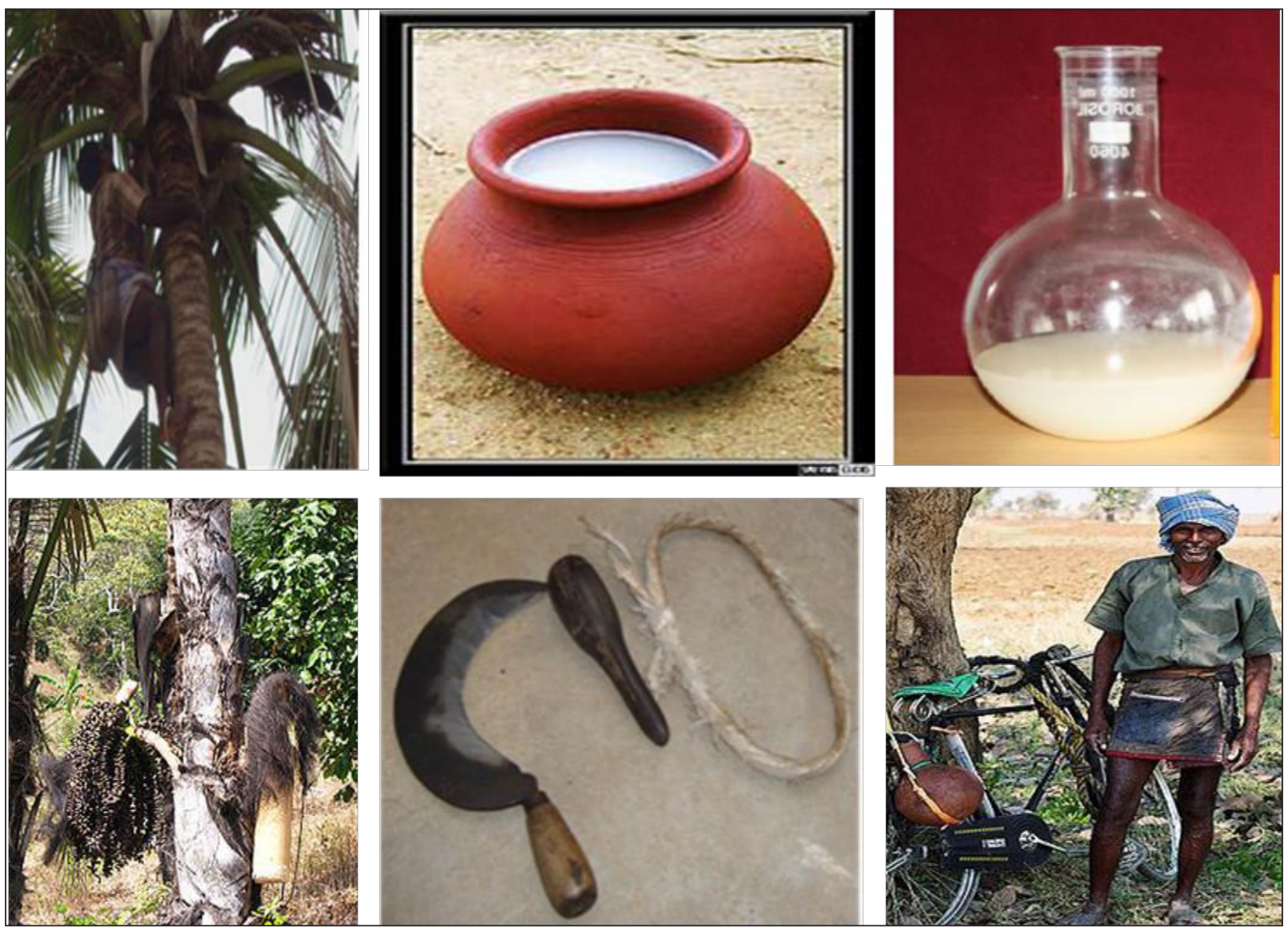

Fig. 3: Palm /Toddy wine collection and Toddy collector in Andhra Pradesh

(From left to right 1. Coconut tree, 2. Toddy wine in earthen pot, 3. palm wine collected in glass beaker, 4. Palm tree, 5. Instruments used to collect palm/toddy wine and 6 . Toddy collector)

Source: Half yearly report on standardization of selected ethnic fermented foods and beverages by rationalization of indigenous knowledge C30031.

intoxicating, whereas Thati Kallu is stronger (sweet in the morning, becoming sour to bitter-sour in the evening) and is highly intoxicating. A small amount of toddy from the previous day's fermentation should be left in the pot to start the fermentation (Fig. 3). A natural fermentation takes place due to yeasts that are present in the sap and those that are added from a previous batch of toddy. The sugar in the sap is partly fermented to alcohol, which helps to preserve the product. It requires refrigeration if it needs to be stored for more than 24 hours. The collecting pots should not be washed out. That way they retain a small amount of starter inoculum for future fermentations. However, it is important to ensure that they are kept clean and do not become contaminated by other bacteria. The fermentation vessels should be kept clean and the product must be hygienically handled (Law et al. 2011). Shamala and Sreekantiah (1988) reported that the fermentation produces mainly ethanol, acetic acid and lactic acid. $\mathrm{pH}$ of the sap rapidly dropped from around 7.2 to 5.5 due to formation of acetic acid and ethanol content drastically increased to $5 \%(\mathrm{v} / \mathrm{v})$ within 8 hours. Palm wine contains 5\% (v/v) ethanol, lactic and acetic acids $1-1.5 \%$. Palm wine was found rich in mineral as it contains $0.019-0.028 \%(\mathrm{w} / \mathrm{v})$ of vitamin B-12 and $0.008 \%$ of ascorbic acid (Van Pee and Swings, 1971; Steinkraus, 1994). 
The palm sap fermentation involved alcoholiclactic-acetic acid fermentation, by the presence of mainly yeasts and lactic acid bacteria. Aidoo et al. (2006) concluded that Saccharomyces spp. present in the natural fermented palm sap and are important for the formation of characteristic aroma of the palm wine. S. cerevisiae and S. pombe have been reported to be the dominant yeast species (Odunfa and Oyewole, 1998). Other yeast species such as other Candida spp and Pichia spp. are also present (Atacador-Ramos, 1996). Lactic acid bacteria and other bacteria such as Lactobacillus plantarum, L. mesenteroides, Acetobacter spp. and Zymomonas mobilis are also present. The microorganisms are reported to originate from the palm tree, the gourd used for sap collection and fermentation, or the tapping equipment. Study done by Atputharajah et al. (1986) reported the presence of seventeen (17) species of yeasts and seven (7) genera of bacteria in the natural fermented coconut palm sap. Yeast species found include the Candida paropsilosis, C. tropicalis, C. valida, K. javanica, Pichia etchellsii, P. farinose, P. guilliermondi, P. membranaefciens, P. ohmeri, Rhodotorula glutinis, Saccharomyces chevalieri, S. ludwigii, S. bailii, Schizosaccharomyces pombe, Sporobolomyces salmonicolor and Torulopsis spp. Bacillus is the predominant bacteria genus while others included Enterobacter, Leuconostoc, Micrococcus and Lactobacillus.

\section{Sara}

Sara is a distilled liquor and very popular alcohol beverage/drink in villages of Andhra Pradesh which also called Naatusarai (country Sara). It is use to prepare in festive seasons like Sankranthi, Ugadi and Vijayadasimi. It contains high alcohol concentration around $20-25 \%(\mathrm{v} / \mathrm{v})$. Rice flour, black jiggery and bark of white accasia tree are used in the preparation of Sara. It is prepared by anaerobic fermentation with in porous earthen pots that kept in deep soil for 10-15 days. After the fermentation it is distilled using pot distillation method. In some varieties different fruits/ and nuts banana, orange, guava, mango also used to get best quality Sara. But after the fermentation the Sara prepared with the addition of fruits and nuts is filtered through sieves and resulting filtrate is consumed directly.

\section{CONCLUSION}

Fermented foods is important to human's diet and possess a natural and healthy image. Traditional fermented foods of Andhra Pradesh (AP) are prepared at the house hold level and only few are commercialized. There are very few reports on traditional fermented foods of Andhra Pradesh. Most of the countries have been well investigated and documented their traditional fermented foods and beverages. In India and in Andhra Pradesh, most of the traditional fermented foods and beverages are yet to be investigated. Only a few common fermented foods such as idli, dosa, dahi have been studied so far. Isolation, purification and identification of dominant microorganisms involved in traditional fermented foods and beverages are important aspects of such studies. Identification of predominant microorganisms through phenotypic and genotypic molecular methods such $16 \mathrm{~S}$ rRNA sequences, FISH, metagenomics tools with the aid of computer informatics, chemotaxonomic tools such as cellwall studies, cellular fatty acids and isoprenoid, quinones are helpful, when the conventional methods of identification is not possible. Due to the presence of various ethnic groups in India we have a diversified food habits. There is a need to study the microbial diversity associated in fermented foods may contribute a significant gene pool, which must not be lost in this generation. This is right time to commercialize our popular and acceptable traditional fermented foods, some of which may present unknown potent microorganisms which could be of scientific interest or may have potential industrial application.

\section{REFERENCES}

Achaya, K.T. 1998. Indian Food: A Historical Companion. Oxford University Press. London.

Adams, M.R. 1999. Safety of industrial lactic acid bacteria. J. Biotechnol., 68: 171-178.

Aidoo, K.E, Nout, M.J.R. and Sarkar, P.K. 2006. Occurrence and function of yeasts in Asian indigenous fermented foods. FEMS Yeast Res., 6: 30-39. 
Aneja, R.P. 2002. Technology of Indian milk products; Dairy India Publication, New Delhi.

Antonio Cobo Molinos, Antonio Gálvez, Anup Raj, Arjun Chauhan, Ashok Das Gupta, Fook Yee Chye, George F. Rapsang, Ghan Shyam Abrol, Idahun Bareh, Ishige Naomichi, Kenneth Ruddle, Kheng Yuen Sim, María José Grande Burgos, Rubén Pérez Pulido, Samuel Oluwoleogundele, Sangeeta Sharma, Sharmila Thokchom, S.R. Joshi, V.K. Joshi, Vandita Chauhan, Vidhan Jaiswal, Vinay Chandel, and Zuberi M Bira (2016). Ch.1. Indigenous fermented foods of South Asia-an overview. In: Indigenous Fermented Foods of South Asia. V.K. Joshi, ed. pp. 1-52. Taylor and Francis, CRC Press, Boca Raton, Florida.

Atacador-Ramos, M. 1996 Indigenous fermented foods in which ethanol is a major product. In Handbook of Indigenous Fermented Foods, ed. Steinkraus, K.H, 363-508, New York: Marcel Dekker.

Atputharajah, J.D., Widanapathirana, S. and Samarajeewa U. 1986. Microbiology and biochemistry of natural fermentation of coconut palm sap. Food Microbiol., 3(4): 273-280.

Attaie, R. 1987. Inhibition of growth of Staphylococcus aureus during production of acidophilus yoghurt. J. Food Protection., 50: 224-228.

Campbell-Platt, G. 1987. Fermented foods of the world - a dictionary and guide. London, Butterworths. ISBN: 0-40700313-4

Gandhi, D.N. 1986. Commercialization of fermented milk products manufacturing by small dairy entrepreneurs in India. Ind. Dairyman., 38(3): 99-104

Gandhi, D.N. 1989. Dahi and Acidophilus milk; Indian Dairyman, 41: 323-327

Gandhi, D.N. 2002. Potential application of lactic acid bacteria for the development of fermented milk products and in bioprocessing of whey. Indian Dairyman, 54(12): 64-67.

Ghosh, D. 2010. Application of principal component analysis (PCA) as a sensory assessment tool for fermented food products. Journal of Food Science and Technology. JFST-D-09-00006.

Grimwood, B.E. and Ashman, F. 1975. Coconut Palm Production: Their Process in Developing Countries. Food and Agriculture Organization, pp. 189-190.

Hansen, E.B. 2002. Commercial bacterial starter cultures for fermented foods of the future. Int. J. Food Microbiol., 78: 119131.

Joshi, V.K., Garg, V. and Abrol, G.S. 2011. Indigenous fermented foods. In: Food Biotechnology: Principles and Practices. Joshi, V.K. and Singh, R.S. (Eds). IK International Publishing House. New Delhi, pp. 337-373.

Joshi, V.K. 2012. Health benefits and therapeutic value of fermented foods. In Health Foods: Concept, Technology and
Scope. Gupta, R.K., Bansal, S., and Mangal, M., Eds. Biotech, New Delhi, pp. 183-235.

Joshi, V.K., Sharma Somesh and Thakur, N.S. 2013. Traditional Fruits and vegetables fermentation technology. In: Food Processing and Preservation. Eds. Bakshi A.K., Joshi V. K., Vaidya D. and Sharma S. Jagmander Book Agency, New Delhi, pp. 553-570.

Joshi, V.K. 2016. (Ed). Indigenous Fermented Foods of South Asia. Rob Nout and Prabir Sarkar, Series Eds, The Fermented Foods and Beverages Series, CRC Press, Roca, Florida, USA, pp 851+figs.

Laxminarayan, H. and Shankar, P.A. 1980. Fermented milk in human nutrition. Indian Dairyman., 32(2): 121-129.

Lindsay, R.C. 1965. Green flavor detect in lactic starter cultures. J. Dairy Sci., 48: 863-869.

Mann, G.V. 1977. A factor in yogurt which lowers cholesteremia in man. Atherosclerosis., 26(3): 335-40.

Mukherjee, S.K. 1965. Role of Leuconostoc mesenteroides in leavening the batter of $i d l i$, a fermented food of India. J. Appl. Microbiol., 13: 227-231.

Nout, M.J.R. 2001. Fermented foods and their production. In: Fermentation and Food Safety 1-30, Gaithersburg, Md: Aspen Publishers, Inc.

Odunfa, S.A. and Oyewole, OB. 1998. African fermented foods. In Microbiology of Fermented Foods, Vol. 2, ed. Wood, B.J.B, 713-752, London: Blackie Academic and Professional.

Pederson, 1960. Sauerkraut. In advances in food research, ed. C.O. Chichester, E.M. Mark, and G.F. Stewart, Vol. 10, 233260, New York: Academic Press.

Radhakrishnamurty, R. 1961. Studies on idli fermentation: Part II Relative participation of black gram flavour and rice semolina in the fermentation. J. Sci. Indus. Res., 20: 342-345.

Ragavendra Rao, S.N. 1979. Characteristics of roti, dosa and vermicelli from maize, sorgam and bajra. J. Food Sci. Technol., 16: 21-24.

Ramakrishnan, C.V. 1979. The studies on Indian fermented food. Baroda J. Nat., 6: 1-57.

Ramakrishnan, C.V. 1993. Indian idli, dosa, dhokla, khaman and related fermentations. In Handbook of indigenous fermented foods, ed. Steinkraus KH, 149-165, New York, Marcel Dekker.

Rangappa, K.S. and Achaya, K.T. 1974. Indian Dairy Products. 2nd edition, Asia Publishing House, Bombay, pp. 119-124.

Ray, R.C. and Joshi, V.K. 2014.. Fermented foods: past, present and future micro organisms and food fermentations.1. Traditional fermented foods. R.C. Ray and Didier Montet Eds, Volume 1 Food Biology Series, CRC Press New York, pp. 1- 36 .

Sandhu, D.K. and Soni, S.K. 1986. In yeast Biotechnology. Haryana Agricultural University Press. Hisar. 
Sankaran, R. 1998. Fermentated foods of the Indian subcontinent. In Microbiology of fermented foods Vol II, ed. Brian J.B. Wood, London, Thomson Science.

Sarkar, S. 1996. Organoleptical, microbiological and chemical quality of misti dahi sold in different districts of West Bengal. Ind. J. Dairy Sci., 49(1): 54-61.

Sekar, S. and Mariappan, S. 2005. Usage of traditional fermented products by Indian rural folks and IPR. Ind. J. Trad. Knowledge, 6(1): 111-120.

Sekhar, S. and Mariappan. 2007. Usage of traditional fermented foods by Indian rural folks and IPR. Ind. J. Trad. Knowledge, 6: 111-120.

Shamala, T.R. and Sreekantiah, K.R. 1988. Microbiological and biochemical studies on traditional Indian palm wine fermentation. Food Microbiol., 5(3): 157-162.

Soni, S.K. 1986. Microbiological studies on Dosa fermentation. Food Microbiol., 3: 45-53.

Soni, S.K. 1985. Studies on dosa - an indigenous indian fermented food: Some biochemical changes accompanying fermentation. Food Microbiol., 2: 175-181.

Soni, S.K. 1989a. Fermentation of Idli: effects of changes in raw materials and physico-chemical conditions. J. Cereal Sci., 10: 227-238.

Soni, S.K. 1989b. Nutritional improvement of Indian doss batters by yeast enrichment and black gram replacement. J. Ferment. Bioeng., 68: 52-55.

Soni, S.K. and Sandhu, D.K. 1990. Indian fermented foods: Microbiological and biochemical aspects. Ind. J. Microbiol., 30: 135-157.
Sreenivasan, M.R. and Benarjee. 1946. Studies on menthods of preparation of gheeII souring process. Indian Journal of Veterinary Science and Animal Husbandry, 16: 72-83.

Steinkraus, K.H. 1967. Studies on idli- An Indian fermented black gram rice food. Food Technol., 21: 916-919.

Steinkraus, K.H. 1994. Nutritional significance of fermented foods. Food Research International, 21: 259-261.

Tamang, J.P. and Holzapfel. 1999. Biochemical identificaton techniques-modern techniques: Microfloras of fermented foods. Encyclopaedia of Food, pp. 249-252.

Thyagaraja, N. 1991. Micro-ora in idli a traditional fermented cereal-pulse product from India. Leben-Wisse. Technol., 24: 504-507.

Thyagaraja, N. 1992. Studies on microbiological changes during the fermentation of idli. Leben-Wisse. Technol., 25: 77-79.

Van Pee, W. and Swings, J.J. 1971. Chemical and microbiological studies of Congolese palm wines (Elaeis guineesis). East. Afr. Agricul. Forest. J., 36: 311-14.

Venkatasubbaiah, P. 1984. Microbiological and physicochemical changes in idli batter during fermentation. J. Food Sci. Technol., 22: 59-63.

Venkatasubbaiah, P. 1985. Involvement of yeast flora in idli batter fermentation. J. Food Sci. Technol., 22: 88-90.

Verma, L.R. and Joshi, V.K. 2000. Postharvest technology of fruits and vegetables: handling, processing, fermentation, and waste management. Indus Publications and Co., New Delhi, 1055-1057. 
